\title{
Assessment of Pesticide Residue Levels in Vegetables sold in some Markets in Lagos State, Nigeria
}

\author{
Njoku, K. L., Ezeh, C. V., Obidi, F. O. and Akinola, M. 0. \\ Department of Cell Biology and Genetics, University of Lagos, Akoka, Lagos.
}

\begin{abstract}
This study investigated pesticide residue levels in the two vegetables commonly eaten in Lagos state Nigeria. The vegetables (Telfairia occidentalis and Celosia argentea) were purchased from six markets (Oyingbo, Mile 12, Mushin, Ajah, Agege and Festac) in Lagos. The pesticide residue levels were determined using gas chromatography/mass spectrometry. Data obtained were statistically analysed using graph pad prism 6.0 software and were compared with WHO limits. The vegetables from all the markets had pesticide residue level above the WHO lower limit $(0.02 \mathrm{mg} / \mathrm{kg})$. The two vegetables from Oyingbo and Mile 12 markets had total pesticide residue levels above the WHO upper limit $(0.7 \mathrm{mg} / \mathrm{kg})$. T. occidentalis from Oyingbo market had the highest total pesticide residue level $(2.35 \mathrm{mg} / \mathrm{kg})$ and the highest number of pesticides while $C$. argentea from Agege market had the least total pesticide residue level $(0.08 \mathrm{mg} / \mathrm{kg})$. Aladrin was found in the two vegetables from all markets and generally more pesticide residue was found in the tissues of $T$. occidentalis than in the tissues of $C$. argentea. Significant differences $(P<0.05 ; P<0.01)$ were noticed between some pesticides in $T$. occidentalis from Oyingbo and some pesticides in the vegetables from the other markets. Although the hazard quotient and hazard index values (being less than 1 and 0.2 respectively) indicate that there will be no health risk in consuming the vegetable, some of pesticides residues were above the maximum residue levels. The presence of pesticides in the vegetables calls for strict regulation of the application of the pesticides in farms and preservation chambers. This will help in preventing some of the diseases and other problems associated with pesticide accumulation.
\end{abstract}

Keywords: Pesticide, Residue, Vegetable, Health Risk, Monitoring Correspondence: knjoku@unilag.edu.ng, kecynjoku@gmail.com

\section{Introduction}

Pesticide residue refers to the pesticides that may remain on or in food after they are applied to food crops. It is defined by WHO (2016) as any substance or mixture of substance in food for man or animals resulting from the use of pesticide and includes any specified derivatives, such as degradation and conversion products, metabolites, reaction products, and impurities that are considered to be of toxicological significance. Waldrum et. al. (1996) defined a pesticide as any product that kills or control various types of pest (plant or animal that is harmful to man or the environment).
Pesticides are used in agriculture to protect crops against insects, fungi, weeds and other pests as well as to protect public health in controlling the vectors of tropical diseases like mosquitoes. They can also be used to prevent, destroy, repel or mitigate any pest and can either kill pests or render them ineffective (Cassida, 2009). Pesticides are used on fruits, vegetables, wheat, rice, olives, canola pressed into oil and on non-food crops such as cotton, grass and flowers.

Pesticides applied to food crops in the field can leave potentially harmful residues (Botwe et. al., 2011). According to Keikotlhaile and Spanoghe (2011), after pesticides are applied to the crops, they may interact with the plant surfaces, be exposed to the 
environmental factors such as wind and sun and may be washed of during rainfall. The pesticide may be absorbed by the plant surface (waxy cuticle and root surfaces) and enter the plant transport system (systemic) or stay on the surface of the plant (contact). The pesticides that get into the plant tissues may be transformed (metabolised) or sequestered in the tissues to form the pesticide residue.

Pesticide residues are the deposits of pesticide active ingredient, its metabolites or breakdown products present in some component of the environment after its application, spillage or dumping (Dasika et. al., 2012). The presence of pesticide residues is a concern for consumers because pesticides are known to have potential harmful effects to other non-targeted organisms than pests and diseases (Keikotlhaile and Spanoghe, 2011).

Infants, children and adults are commonly exposed to pesticides by eating them on and in our food (CEEH, 2013). Consumption of conventionally grown fruits and vegetables is a major source of nonoccupational pesticide exposure (Chiu et. al., 2015). Vegetables consumption is usually encouraged because according to Botwe et. al. (2011) they are essential for a healthy and balanced diet, as well as adding variety, interest and flavour to the menu.

Pesticides are potentially toxic to humans and have been linked to a wide range of human health hazards, ranging from shortterm impacts such as headaches and nausea to chronic impacts like cancer, reproductive harm, and endocrine disruption (TAC, 2015). Children in particular may be susceptible to adverse neurological, developmental and other effects from pesticides exposures (CPDIC, 1993; Weiss et. al., 2004). They may induce adverse health effect including cancer, effects on reproduction, immune or nervous systems (WHO, 2016) and have been implicated as one of the potential reproductive toxicants responsible for decline in semen quality (Chiu et. al., 2015). Whorton et. al. (1977) indicated that a number of cases of infertility such as azoospermia, oligospermia, and high serum levels of FSH and LH were discovered in 1970s in pesticide factory and due to longer occupational exposure to 1,2-dibromo-3chloropropane (DBCP).

Kelce et. al. (1994) and Perry et. al. (2011) similarly reported low levels of pesticide exposure may have anti-androgenic effects. Pesticide exposure whether occupational or environmental have be linked to decreased semen quality parameters particularly sperm concentration (Perry, 2008; Martenies and Perry, 2013).

Studies have shown that vegetable intake is positively related in urinary metabolites levels of pyrethroid pesticides (Fortes et al., 2013). Pyrethroid pesticides and metabolites 3-pherooxybenzoic acid (3-BPA) and trans-3-(2,2-dichlorovinyl)-1methylcyclopropane-1,2-dicarboxylic acid (TDCCA) are associated with lower sperm concentration. High $\mathrm{p}, \mathrm{p}$ dichlorodiphenyldichloroethylene (DDE) increased the odds of low sperm motility and abnormal morphology (Bretveld et al., 2007; Recio-vega et. al., 2008). Organophospates are associated with decreased sperm concentration, ejaculate volume and total sperm count (Perry et al., 2011).

Chiu et. al. (2015) also showed that intake of high pesticide residue in fruits and vegetables were inversely associated with total sperm count, ejaculate volume and percentage of morphologically normal sperm. They suggested that dietary exposure to pesticide used in agriculture may impact semen quality in men. Both environmental and occupational exposures to pesticides were most commonly associated with a decrease in sperm concentration.

Pesticides like endosulfan, metamidphos, dimethoate and methylparathion have been shown to increase apoptosis during spermatogenesis (Recio-vega et. al., 2008). Organophosphates, bipyridyl herbicides and organochlorines produce free radicals that induce oxidative stress and cause dysfunction (Abdollahi et. al., 2004). Parathion and methyparathion structurally mimic estrogen and interact with hormone receptors and interfere in gene transcription.

The aim of this study was to assess the level of pesticide residue in the vegetables commonly consumed in Lagos State, Nigeria to and to estimate the health risks associated with such. There is paucity of information on the pesticide residue in the vegetables consumed in Lagos. However, going by the available information from researches from other parts of the world on the presence of pesticides in food (Botwe et. al., 2011; Petersen et. al., 2013; Qin et. al., 2016) and their toxic potentials it is important to have information on the pesticide residues and associated risk of consuming vegetables with pesticides in Lagos. 


\section{Methodology}

Sampling of vegetables

Sampling of the vegetables was done as described by Botwe et al. (2011). Two vegetable namely Telfairia occidentalis and Celosia argentea were purchased from each of six local markets located at Oyingbo, Mile 12, Mushin, Ajah, Agege and Festac areas Lagos, Nigeria (Fig. 1). The vegetables were considered representative of the commonly consumed vegetables in Lagos. At each market, vegetable samples were collected from three randomly selected sellers. Two composite samples of identical vegetable items (each containing $3 \mathrm{~T}$. occidentalis and $3 \mathrm{C}$. argentea) were drawn from each market. The samples were wrapped in aluminium foil according to type, properly labelled, packed in polythene bags, and transported to the laboratory Samples were kept in a freezer at $4^{\circ} \mathrm{C}$ until required for extraction.

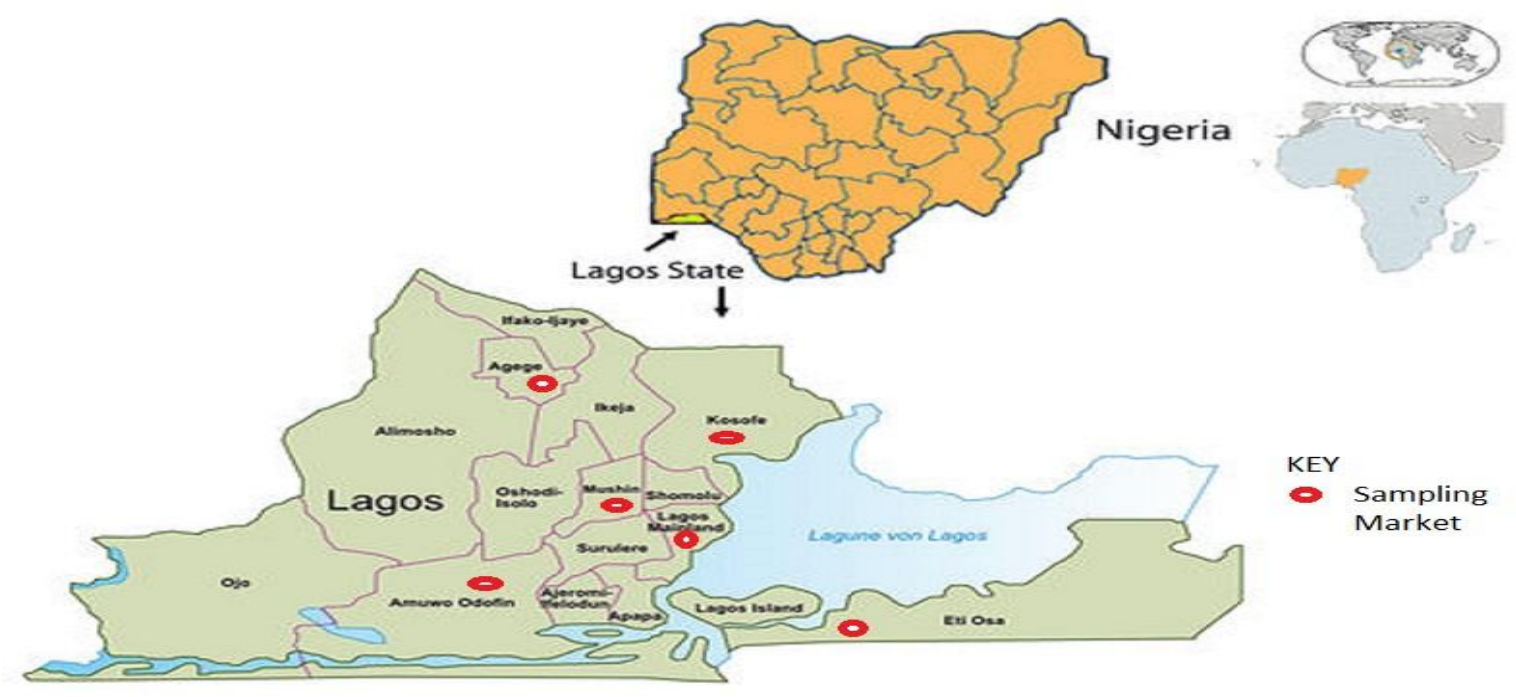

Figure 1: Map of Lagos state, Nigeria showing the sampling sites

\section{Sample preparation}

Sample preparation and extraction followed the procedures described by Ferrer et. al. (2005). About $(10 \mathrm{~g})$ of each vegetable was weighed into a porcelain mortar, and ground with $50 \mathrm{~g}$ of anhydrous sodium sulphate. The powdered sample was extracted in ethyl acetate. The extract was rotary evaporated at $40^{\circ} \mathrm{C}$, and the residue redissolved in hexane. Sample clean-up was done following the procedure of described by Hsu et. al. (1991).

\section{Determination of pesticide residue levels}

The analysis of vegetable samples for pesticide compounds was performed as was described by Botwe et. al. (2011) on a GC-MS (Agilent 6890 Series GC System) coupled with an Agilent 5973N mass selective detectorelectron impact ionization. The capillary column was HP-5MS (length $30 \mathrm{~m}$; I.D 0.25 $\mathrm{mm}$ and film thickness $0.25 \mu \mathrm{m}$ ) and packed with $5 \%$ phenyl methyl siloxane. The GC-MS was operated in the selected ion-monitoring mode at the following conditions: injection port $250^{\circ} \mathrm{C}$ (splitless, pressure $22.62 \mathrm{psi}$; purge flow $50 \mathrm{ml} / \mathrm{min}$; purge time $2.0 \mathrm{~min}$; total flow $55.4 \mathrm{ml} / \mathrm{min})$. Column oven: initial $70^{\circ} \mathrm{C}$ held 2 min, programming rate $25^{\circ} \mathrm{C} / \mathrm{min}$ (70 to $\left.150^{\circ} \mathrm{C}\right) ; 10^{\circ} \mathrm{C} / \mathrm{min}\left(150\right.$ to $\left.200^{\circ} \mathrm{C}\right) ; 8^{\circ} \mathrm{C} / \mathrm{min}$ (200 to $280^{\circ} \mathrm{C}$ ) and held $10 \mathrm{~min}$ at $280{ }^{\circ} \mathrm{C}$. The carrier gas was nitrogen at $15 \mathrm{psi}$; detector make-up, $30 \mathrm{ml} / \mathrm{min}$. The injection volume was $1 \mu \mathrm{l}$ (Agilent 7683 Series injector).

\section{Health risk}

This involved the calculation of the hazard quotient and hazard indices of the different vegetables from the different markets. The hazard quotient (HQ) was calculated using the formula below as was stated by Lozowicka et. al. (2013):

The reference dose is interpreted as the Tolerable Daily Intake (TDI; mg/kg/day). The hazard index of the vegetables from the different market was calculated as sum of the hazard quotient for the markets.

The estimated dose was determined using the information obtained from Hart et. al. (2005) for vegetable consumption in Nigerian cities 
while the formula used was as shown in Lozowicka et. al. (2013)

Estimated Daily intake

$=$ food consumption data $X$ Residue Level Mean body weight

\section{Statistical analyses}

Statistical differences among the different pesticides in the vegetables from the different markets were determined using a two-way ANOVA. The multi-comparison analyses were done using Turkey posthoc test at $\mathrm{p}<0.05, \mathrm{p}<0.01$ and $\mathrm{p}<0.001$. Also correlation analyses were used to compare the pesticide residues from the different markets. All analyses were performed with Graphpad 6 software.

\section{Results}

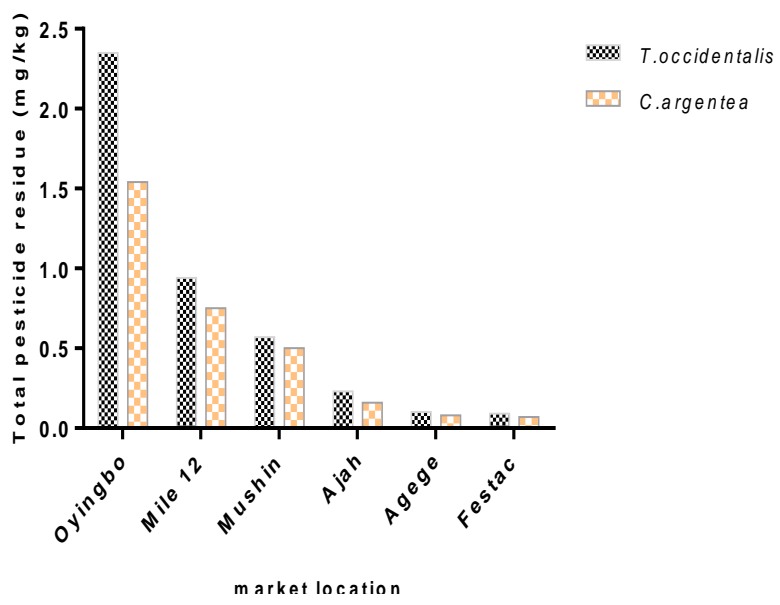

Figure 2: The Total pesticide residue levels in $T$. occidentalis and $C$. argentea from the Different Markets

The residue levels of the different pesticides detected in the tissues of $T$. occidentalis from the different markets are shown in table 1. Only two pesticides (atrazine and diazinon)
The total pesticide residue levels in $T$. occidentlais and $C$. argentea from the different markets

The total pesticide residues in each of the vegetables ( $T$. occidentalis and $C$. argentea) from the different markets are shown in figure 2. Generally, the pesticide in the tissue of $T$. occidentalis from each market was more than that the residue level in $C$. argentea from same market. Also more pesticide was detected in the tissue of the vegetables from Oyingbo with those in the tissues of the vegetables from Agege and Festac being the least. The level of pesticide residues in the tissue of $T$. occidentlais from Oyingbo was generally significantly higher than the pesticide residue in the vegetables from other markets $(p<0.05)$.

The pesticide residues in both vegetables were positively correlated with each other $(r=0.994)$ were detected in the vegetable from the Festac market and the vegetable from Agege market contained only three pesticides (aladrin, atrazine and diazinon). Dicamba, atraton, bromacil, endofulsan, oxamyl and trifluracin were only detected in the vegetable tissue from Oyingbo market.

Generally more pesticides (in number and quantity) were detected in the tissue of $T$. occidentalis from Oyingbo market. The pesticide residue in $T$. occidentalis had a negative correlation with the residues in the vegetable from Mushin and Agege markets ( $r$ $=-0.057$ and $p=-0.083$ respectively) Mile 12 and Mushin. The level of alachlor from Mile 12 market was significantly different from the levels of other pesticides from the other markets $(p<0.05 ; p<0.01 ; p<0.001)$ with the exception of atrazine and bromacil from Oyingbo, cyanzine from Oyingbo and Mile 12 and diazinon from Oyingbo, Also the level of alachlor in the tissue of the vegetable from Oyingbo market was significantly lower than the alachlor level in the vegetable from Mile 12 market $(p<0.01)$

$$
\mathrm{HQ}=\frac{\text { dose rate }}{\text { reference dose }}=\frac{\text { exposure concentration }}{\text { reference concentration }}=\frac{\text { Estimated Dose }(\mu \mathrm{g} / \mathrm{kg} / \mathrm{day})}{\text { Tolerable Daily Intake }(\mu \mathrm{g} / \mathrm{kg} / \mathrm{day})}
$$


Table 1: The Pesticide Residues in Telfairia occidentalis from the Different Markets

\begin{tabular}{ccccccc}
\hline Pesticide & Oyingbo & Mile 12 & Mushin & Ajah & Agege & Festac \\
\hline Alachlor & 0.035 & 0.347 & 0.032 & 0.000 & 0.000 & 0.000 \\
Aladrin & 0.051 & 0.052 & 0.000 & 0.026 & 0.035 & 0.000 \\
Atraton & 0.038 & 0.000 & 0.000 & 0.000 & 0.000 & 0.000 \\
Atrazine & 0.093 & 0.065 & 0.040 & 0.031 & 0.022 & 0.031 \\
Carbofuran & 0.113 & 0.088 & 0.063 & 0.000 & 0.000 & 0.000 \\
Bromacil & 0.081 & 0.000 & 0.000 & 0.000 & 0.000 & 0.000 \\
Cyanazine & 0.167 & 0.118 & 0.088 & 0.000 & 0.000 & 0.000 \\
Dacthal & 0.078 & 0.000 & 0.000 & 0.000 & 0.000 & 0.000 \\
Diazinon & 0.178 & 0.133 & 0.086 & 0.058 & 0.024 & 0.041 \\
Dicamba & 0.094 & 0.000 & 0.000 & 0.000 & 0.000 & 0.000 \\
Diuron & 0.231 & 0.057 & 0.046 & 0.040 & 0.000 & 0.000 \\
Endosulfen & 0.087 & 0.000 & 0.000 & 0.000 & 0.000 & 0.000 \\
Fonofos & 0.176 & 0.059 & 0.049 & 0.032 & 0.000 & 0.000 \\
Oxamyl & 0.035 & 0.000 & 0.000 & 0.000 & 0.000 & 0.000 \\
Propazine & 0.110 & 0.066 & 0.052 & 0.000 & 0.000 & 0.000 \\
Sulprofos & 0.106 & 0.082 & 0.000 & 0.000 & 0.000 & 0.000 \\
Trifluracin & 0.215 & 0.000 & 0.000 & 0.000 & 0.000 & 0.000 \\
\hline
\end{tabular}

Table 2: The Pesticide Residues in Celosia argentea from the Different Markets

\begin{tabular}{ccccccc}
\hline Pesticide & Oyingbo & Mile 12 & Mushin & Ajah & Agege & Festac \\
\hline Alachlor & 0.034 & 0.032 & 0.025 & 0.025 & 0.027 & 0.000 \\
Atrazine & 0.093 & 0.040 & 0.031 & 0.025 & 0.019 & 0.029 \\
Carbofuran & 0.111 & 0.079 & 0.061 & 0.000 & 0.000 & 0.000 \\
Cyanazine & 0.119 & 0.103 & 0.000 & 0.000 & 0.000 & 0.000 \\
Diazinon & 0.178 & 0.120 & 0.062 & 0.051 & 0.025 & 0.041 \\
Dicamba & 0.048 & 0.000 & 0.000 & 0.000 & 0.000 & 0.000 \\
Diuron & 0.143 & 0.460 & 0.000 & 0.000 & 0.000 & 0.000 \\
Endosulfan & 0.085 & 0.000 & 0.000 & 0.000 & 0.000 & 0.000 \\
Fonofos & 0.115 & 0.059 & 0.046 & 0.028 & 0.000 & 0.000 \\
Propazine & 0.120 & 0.052 & 0.046 & 0.000 & 0.000 & 0.000 \\
Sulprofos & 0.106 & 0.071 & 0.000 & 0.000 & 0.000 & 0.000 \\
\hline
\end{tabular}

Table 3: The Pesticide residues, estimated daily intake, hazard quotient and hazard index values of vegetables from all the sampled markets

\begin{tabular}{llllll}
\hline Market & Vegetable & $\begin{array}{l}\text { Pesticide } \\
\text { residue }\end{array}$ & $\begin{array}{l}\text { Estimated daily } \\
\text { intake }\end{array}$ & $\begin{array}{l}\text { Hazard } \\
\text { quotient }\end{array}$ & Hazard Index \\
\hline Oyingbo & T. occidentalis & 2.35 & 3.995 & 0.046453 & 0.070145 \\
& C. argentea & 1.54 & 2.037538 & 0.023692 & \\
Mile 12 & T. occidentalis & 0.94 & 1.243692 & 0.014462 & 0.026 \\
& C. argentea & 0.75 & 0.992308 & 0.011538 & \\
Mushin & T. occidentalis & 0.57 & 0.754154 & 0.008769 & 0.016461 \\
& C. argentea & 0.50 & 0.661538 & 0.007692 & \\
Ajah & T. occidentalis & 0.23 & 0.304308 & 0.003538 & 0.006 \\
& C. argentea & 0.16 & 0.211692 & 0.002462 & \\
Agege & T. occidentalis & 0.10 & 0.132308 & 0.001538 & 0.002769 \\
& C. argentea & 0.08 & 0.105846 & 0.001231 & \\
& T. occidentalis & 0.09 & 0.119077 & 0.001385 & 0.002462 \\
& C. argentea & 0.07 & 0.092615 & 0.001077 & \\
\hline
\end{tabular}


The pesticide residues in Celosia argentea from the different markets

The pesticide residues in the $C$. argentea from the different markets are shown in table 2. Only two pesticides (atrazine and diazinon) were detected in the tissue of the vegetable from Festac market while three pesticides (alachlor, atrazine and diazinon) were detected in the vegetable from Agege market. The vegetable from Ajah had only four pesticides in its tissue namely alachlor, atrazine, diazinon and fonofos. Dicamba was only detected in the tissue of from Oyingbo while atrazine was detected in the tissue of the vegetable from all the markets. Generally the pesticide residue levels were more in the vegetable from Oyingbo.

The pesticide in the tissue of the vegetable from Oyingbo market had correlated negatively $(r=-0.067)$ with the pesticide in the tissue of the vegetable from Agege market. The pesticide in the tissue of the vegetable from Mile 12 market had a negative correlation to the pesticide in the tissue of the vegetable from Mushin, Agege, Ajah and Festac markets $(r=-0.170, r=-0.104, r=-$ 0.135 , and $r=-0.021$ respectively).

The estimated daily intake and hazard quotients of the pesticides due to the consumption of the vegetables are shown in table 3. All the vegetable had Hazard Quotient (HQ) less than 1 with the highest HQ of 0.046 in the T. occidentalis from Oyingbo market and the least HQ value of 0.0010 was in the $C$. argentea from Festac market. The Hazard Index ( $\mathrm{HI})$ was highest in the vegetables from Oyingbo market (0.0701) and lowest in the vegetables from Festac (0.00246).

\section{Discussion}

The essence of pesticide monitoring is to ensure that pesticides in fruits and vegetables do not exceed maximum residue levels (MRLs) allowed by the government, no misuse of pesticides that could result in unexpected residues in food and that good agricultural practices (GAP) are maintained (Keikotlhaile and Spanoghe, 2011). Pesticide residue analysis is tremendously an important process in determining the safety of using certain pesticides (Dasika et. al., 2012). Pesticide residues in fresh produce are a major consumer concern (Keikotlhaile et. al., 2010).

The detection of the different pesticides in the tissues of the vegetables shows that the vegetables were exposed to pesticides at the one stage of their production or another. The exposure could be in the field or at storage sites. The variation in the levels of the pesticide residues detected in the tissues of the vegetables from the different markets could be markets could be attributed to difference in the level and type of pesticide use at the various locations that the vegetable originated from. This is in consonance with earlier studies by Botwe et. al. (2011); Petersen et. al. (2013) and Qin et. al, (2016) that reported differences in pesticide residues in foods items from different locations.

Some health implications have been associated with pesticide residues in food ranging from headaches and nausea to chronic impacts like cancer, reproductive harm and endocrine disruption, and others (Recio-vega et. al., 2008; Berrada et. al., 2010; Gilden et. al., 2010; Chiu et. al., 2015), however the risk analysis result obtained in this study seem to suggests that there is no risk as at the time of the study on the consumption of those vegetables.

Hazard quotient value less than 0.2 and the hazard index values less than 1 for pesticides in all the vegetables further suggest that individuals are not at any health risk from the consumption of these vegetables. This implies that although the vegetables assessed in this study contained pesticides in their tissues, the levels are still low to pose any risk to the consumers of such vegetables as at the time of the study. This however does not foreclose the possible biomagnification and possible health risk of the consumption of vegetables from the same sources in future. This is due to the fact that some pesticides are persistent and thus continuous application of such can lead to higher pesticide residue levels in the soil and subsequent uptake by plants with possibly to levels that health hazards can be manifested.

Comparison of some of the pesticides detected in the tissues of the vegetables (e.g. $T$. occidentalis) with the maximum residue levels (MRLs) stated by TJFCRF (2014) showed that the residue levels of some pesticides were more than the MRLs. For instance the MRLs for diazinon, diuron, bromacil, alachlor and atrazine are $0.1 \mathrm{mg} / \mathrm{kg}, 0.2 \mathrm{mg} / \mathrm{kg}, 0.05$ $\mathrm{mg} / \mathrm{kg}, \quad 0.01 \mathrm{mg} / \mathrm{kg}$, and $0.02 \mathrm{mg} / \mathrm{kg}$ respectively and their respective residue levels in $T$. occidentalis from Oyingbo market are $0.178 \mathrm{mg} / \mathrm{kg}, 0.231 \mathrm{mg} / \mathrm{kg}, 0.081 \mathrm{mg} / \mathrm{kg}$, 
$0.035 \mathrm{mg} / \mathrm{kg}$, and $0.093 \mathrm{mg} / \mathrm{kg}$. This calls for caution in the consumption of the vegetables.

\section{Conclusion}

The presence of pesticide residues in the experimental vegetables used for this study calls for strict measures in the regulation of the use of pesticides for crop protection and yield improvement. Some pesticides are persistent in nature and can bioaccumulate and be biomagnified in the tissues of organisms at the higher trophic level. Proper risk assessment of the consumption of vegetables exposed to pesticides is suggested here. Also there is the need for proper education and enlightenment of farmers on how to use pesticides to avoid problems associated with pesticide poisoning.

\section{References}

Abdollahi, M., Ranjbar, A., Shadnia, S. Nikfar, S., and Rezale, A (2004) Pesticides and Oxidative stress: a review. Med. Sci. Monitor: Int. Med. J. Experim. Clin. Res. 10: RA 141RA147

Berrada H, Fernandez M, Ruiz M.J, Molto J.C., Manes J, and Font G (2010) Surveillance of pesticide residues in fruits from Valencia during twenty months (2004/2005) Food Contam. 21:36-44

Botwe, B. O. Ntow, W. J., Kelderman, P. , Drechsel, P., Carboo, D., Nartey, V. K. and Gijzen, H. J. (2011) Pesticide Residues Contamination Of Vegetables and Their Public Health Implications in Ghana. J. Environ. Issues Agric. Dev. Countries 3 (2): 1-18

Bretveld R, Brouwers, M, Ebisch I and Roeleveld, N. (2007) Influence of pesticides on male fertility. Scand. J. Work Environ. Health 33 (1):13-28.

Cassida, J.E. (2009). Pest toxicology: the primary mechanisms of pesticide action. Chem. Res. Toxicol. 22 (4): $609-619$.

Centre for Ecogenetics and Environmental Health (2013) Fast Facts about Health Risks of Pesticides in Food. https://depts.washington.edu/ceeh/downloads /FF_Pesticides.pdf

Chiu, Y.H., Afeiche, M.C., Gaskins, A.J. William, P.L., Petrozza, J.C., Tanrikut, C., Hauser, R. and Chavarro, J.E. (2015) Fruit and Vegetable intake and their pesticide residues in relation to semen quality among men from fertility clinic. Hum. Reprod. 0(0): 1-10 doi:10.1093/humrep/dev064

CPDIC - Committee on Pesticides in the Diets of Infants and Children (1993). Pesticides in the Diets of Infants and Children. Washington DC. National Research Council.

Dasika R., Tangirala S. and Naishadham, P (2012) Pesticide residue analysis of fruits and vegetables. J. Environ. Chem. Ecotoxic. 4(2): $19-28$

Ferrer, I., García-Reyes, J. F., Mezcua, M., Thurman, E.M. and Fernández-Alba, A.R. (2005). Multi-residue pesticide analysis in fruits and vegetables by liquid chromatography-time of-flight mass spectrometry. J. Chromatography A 1082: 8190

Gilden, R. C.; Huffling, K. and Sattler B. (2010). Pesticides and Health Risks. J. Obs. Gyne. Neo. Nursing 39: $103-110$

Hart, A.D, Azubuike, C.U., Barimalaa, I.S and Achinewhu, S.C (2005) Vegetable Consumption Pattern Of Households In Selected Areas of The Old Rivers State In Nigeria. Afr. J. Food Agric. Nutri. Dev. (AJFAND) 5 (1): 1-18

Hsu R.C., Biggs I. and Saini N. K. (1991). Solid-Phase Extraction Cleanup of Halogenated Organic Pesticides. J. Agric. Fd. Chem. 39, 1658-1666

Keikotlhaile, B. M. and Spanoghe P. (2011) Pesticide Residues in Fruits and Vegetables http://cdn.intechopen.com/pdfswm/13013.pdf

Keikotlhaile, B. M., Spanoghe, P. and Steurbaut. W. (2010). "Effects of Food Processing on Pesticide Residues in Fruits and Vegetables: A Meta-Analysis Approach." Fd. Chem. Toxicol. 48, 1: 1-6

Kelce, W. R., Monosson, E., Gamcsik, M.P., Laws, S.C. and Gray, L.E.Jr. (1994) Environmental hormone disruptors: evidence that vinclozol in developmental toxicity is mediated by antiandrogenic metabolites. Toxicol. Appl. Pharmacol. 126: 276-285.

Khairiah, J; Zalifah, M.K.; Yin, Y.H. and Aminah, A (2004). The uptake of Heavy Metals by Fruit type Vegetables grown in selected 
Agricultural Areas. Pakis. J. Bio. Sci. 7 (8): 1438-1442.

Lozowicka, B. Kaczynski, P., Rutkowska, E., Janowska, M. and Hrynko, I. (2013) Evaluation of pesticide residues in fruits from Poland and health risk assessment. Agric. Sci. 4 (5B) : 106-111

Martenies, S. E. and Perry, M.J. (2013). Environmental and occupational pesticide exposure on human sperm parameters: a systematic review. Toxicol. 307: 66-73

Mensah, J.K; Okoli, R.I; Ohaju-Obodo, J.O and Eifediyi, K (2008). Phytochemical, nutritional and medical properties of some leafy vegetables consumed by Edo people of Nigeria. Afr. J. Biotech. 7 (14): 2304-2309.

Perry, M.J., Venners, S.A., Chen, X., Liu, $X$, Tang, G., Xing, H., Barr, D.B. and $X u, X$. (2011) Organophosphorus pesticide exposures and sperm quality. Reprod. Toxicol. 31: 75-79

Perry, M.J. 2008 Effects of environmental and occupational pesticide exposure on human sperm: a systematic review. Human Reproduction Update, 14: 233-242

Petersen, A., Hamborg, B. J., Andersen, J. H., Poulsen, M. E., Christensen, T. and Nielsen, E. (2013) Pesticide Residues Results from the period 2004-2011. Prepared by National Food Institute, Technical University of Denmark, 138pp. www.food.dtu.dk

Qin, G., Zou, K., Li, Y., Chen, Y., He, F., and Ding, G. (2016). Pesticide residue determination in vegetables from western China applying gas chromatography with spectrometry. Biomed. Chromatography, 30 (9): $1430-1440$.

Recio-Vega, R., Ocampo-Gomez, G., BorjaAburto, V.H., Moran-Martinez, J. and CebrianGarcia, M. E. (2008) Organophosphorus pesticide exposure decrease sperm quality: association between sperm parameters and urinary pesticide levels. J. App. Toxicol. 28:674-680

The Japan Food Chemical Research Foundation (2014) List of pesticide and Maximum Residue limits (MRLs) http://apeda.gov.in/apedawebsite/Announcem ents/Listpesticides MaximumResiduelimits.pdf

Toxic Action Centre (2015). The problems with pesticides.

http://www.toxicsaction.org/problems-andsolutions/pesticides

Waldrum, J.D., Brady, P.L., and Spradley, J.P. (1996). Pesticides Residues in Food: Safety Issue. ipm.ncsu.edu/safety/factsheet.

Weiss, B., Amler, S., and Amler, R.W. (2004). Pesticides. Pediatrics, 113 (4): 1030-1036.

WHO (2016). Pesticide Residues in Food. http://www.who.int/feature/9a/87/en.

Accessed on $28^{\text {th }}$ September, 2016.

Whorton, D, Krauss, R.M, Marshall, S, and Milby, T.H. (1977) Infertility in male pesticide workers. Lancet, 2:1259-1261 